\title{
Is There a Potential for a Translanguaging Approach to English Education in Japan? Perspectives of Tertiary Learners and Teachers
}

\author{
Blake Turnbull \\ Kyoto University
}

Despite recent policy reforms by the Japanese Ministry of Education, Culture, Sports, Science and Technology (MEXT) emphasising a change towards a predominately target-language (TL)-based EFL classroom environment, studies have suggested that desire for L1 use by both English learners and many teachers remains prevalent in Japan. The question, then, becomes whether a resolution exists to balance the rising conflict between government policy and actual classroom practice in Japanese EFL education. The purpose of this study was to investigate the opinions of both Japanese EFL students $(n=373)$ and teachers $(n=261)$ regarding the use of the L1 (Japanese) in the L2 (English) learning process and the ensuing potential to introduce a bilingual translanguaging approach to Japanese EFL education on the whole. The findings suggest that, although there appears to be a space for a translanguaging approach to EFL education in Japan, the success would depend largely on how willing both teachers and students are to take it up and by the level of training and education provided to both sides.

英語の授業は主に英語で行われるべきだということを強調する文部科学省の政策にも関 わらず、授業における日本語使用はまだ日本人学習者にも日本人教師にも好まれている という研究報告がある。これによる大きな問題は、日本の英語教育において、政府の政策 と実際の授業実践の格差に解決策があるのかということだ。本論文は、第二言語（英語） を学習する際の第一言語（日本語）の使用に関する学習者（373名）と教師（261名）の意

JALT Journal, Vol. 40, No. 2, November 2018 
見、そしてそれに基づいたトランスランゲージングの可能性を調査した研究を報告する。 分析の結果、日本の英語教育においてトランスランゲージングの可能性はあるが、その成 功は学習者と教師がそれをどのように受け入れるかと両者が受ける教育と研修に大きく影 響されることが示された。

Keywords: English as a foreign language; Japanese EFL education; student perspectives; teacher perspectives; translanguaging

$\mathrm{T}$ he use of learners' L1 in L2 education has received much criticism in the past. Ever since the deposition of the traditional grammar-translation method due to its inability to develop students' communicative competence through L1 translation alone, there has been a sense of uneasiness held towards the use of the L1 in L2 learning. Even today, these ideologies of distrust towards the L1 may continue to prevail in many dominant L2 teaching approaches (see Cummins, 2007). However, some researchers have suggested that exclusion of the L1 in favour of the exclusive use of the L2 is a politically driven act that has little grounding in pedagogical research or theory and, therefore, may not be as beneficial to L2 teaching and learning as is commonly portrayed (see Auerbach, 1993). Accordingly, the beneficial role of the L1 in L2 learning has begun to receive increased attention amongst scholars of SLA in recent years (see, e.g., Butzkamm, 2011; Carless, 2008; Cook, 2001; Cummins, 2007; Hall \& Cook, 2012; Storch \& Aldosari, 2010; Turnbull \& Dailey-O'Cain, 2009; Turnbull \& Sweetnam Evans, 2017). Strategic and judicious use of the L1 has been identified as both a social and cognitive tool that facilitates L2 learning and remains active at the learner's disposal throughout the L2 learning process.

Research investigating the perspectives of L2 learners (e.g., Brooks-Lewis, 2009), teachers (e.g., Yavuz, 2012), and even preservice teachers (e.g., Turnbull, 2018) towards the use of the L1 has been seen in the past, often showing mixed results. Studies in Japanese contexts have also investigated perspectives regarding L1 use in the education of EFL, which have, in general, shown a positive attitude towards L1 use (see, e.g., Burden \& Stribling, 2003; Hawkins, 2015; Saito \& Ebsworth, 2004). However, recent policy reforms by the Japanese Ministry of Education, Culture, Sports, Science and Technology (MEXT) have emphasised a change towards a predominately target-language (TL)-based classroom environment to maximise students' exposure to English (see MEXT, 2011): a call in direct opposition to the favourable attitudes and desire for the L1 by Japanese EFL learners and many teachers alike. This raises a pivotal and, as of yet, unanswered question: Is there a balanced resolution to benefit both sides? The answer may be yes, but it would 
involve the introduction of a new pedagogical approach - translanguaging, or the integrated use of all languages in which learners' hold proficiency in a systematic, multimodal, and semiotic manner-one that has been largely unseen in a Japanese context; its potential, therefore, remains unknown. In fact, very little, if any, discussion of translanguaging in EFL contexts such as Japan, where L1 vs. L2 use remains a contentious issue for a variety of sociocultural and policy-related reasons, has occurred thus far in the literature. The first barrier to successfully introducing a new approach such as translanguaging to an EFL education context, especially one such as Japan, which has long perpetuated a traditional exam-based grammar system in which the use of the L1 is frequent, is ensuring that those involved in the learning process (i.e., the teachers and the learners) are themselves willing to accept it. The aim of the present study was thus to investigate the opinions of both Japanese EFL teachers and students regarding the use of the L1 (Japanese) in the L2 (English) learning process and the potential for a bilingual translanguaging approach to balance the rising conflict between government policy and actual classroom practice in Japanese EFL education.

\section{English in Japanese Education}

It has been widely recognised that the English language abilities of Japanese students are relatively low (see Aoki, 2017; Butler \& Iino, 2005). EFL education in Japan has faced major criticism throughout the past 50 years in particular for failing to produce proficient English-speaking Japanese people. To address this issue, MEXT took a step towards internationalisation and improving the nation's English ability in their (2003) Action Plan to Cultivate Japanese with English Abilities. Unfortunately, this was widely ignored until MEXT made it a central part of their (2011) revision to the national course of study guidelines, in which they stipulated that "English classes should be conducted principally in English in high school" (p. 8). MEXT's (2014) English Education Reform Plan Corresponding to Globalization stipulates English classes at the junior high school level to be conducted "basically" in English as well as the introduction of new English Language Activities at the lower elementary level and English Language as a subject at the upper elementary level in the lead up to 2020. Even tertiary level policies, such as MEXT's Top Global University Project, have advocated for English-medium courses in the promotion of internationalisation of select tertiary institutions, although the use of Japanese in such programmes is still reported (see Bradford \& Brown, 2018). Thus, the suggestion to largely remove Japanese from the EFL classroom, particularly at the junior and senior high school 
levels but also at the tertiary level, has been met with some resistance, and even today many classrooms are yet to fully exclude the L1, despite the governmental policies in favour of doing so.

Japanese has been, and in most cases continues to be, the traditional language of instruction in Japanese EFL classrooms (Terauchi, 2017). This is perhaps because of the grammar- and vocabulary-based system in use at the high school level (see Butler \& Iino, 2005), where L1 use is high, and Japan's national culture of learning, which may play a significant influential role on the psychological mindset and actions of both Japanese EFL teachers and students. Samimy and Kobayashi (2004), for example, claim there to be "cultural mismatches" (p. 253) between theoretical foundations of TLbased communicative language teaching (CLT) and the Japanese culture of learning. Hobbs, Matsuo, and Payne (2010) agreed, suggesting that certain forms of CLT are "incompatible" (p. 46) with EFL in contexts such as Japan because the culture of learning is different to that of the western countries in which said CLT methods were developed (Littlewood, 2007). If we take this as true, we understand that developing EFL abilities in Japanese students through TL-exclusive CLT approaches will likely prove ineffective, and we must, therefore, look at ways to balance traditional methods (in which use of the L1 is common) with new and more effective means of improving learners' overall EFL abilities. One such potential for this is a translanguaging approach.

\section{Translanguaging and Emergent Bilinguals}

García (2009) propagated the term emergent bilinguals to refer to "students who are in the beginning stages of moving along a bilingual continuum" (p. 397, Chapter 2, Note 2): in other words, those in the process of acquiring an additional language to their first. Turnbull (2016) extended the term to specifically include FL learners in their own right, redefining an emergent bilingual as "any person who is actively in the process of acquiring knowledge of a second language and developing bilingual languaging skills for use in a given situation relevant to their individual needs to learn the TL" (p. 3 ). The inclusion of FL learners within this framework is significant as it recognises FL learners as possessing unique bilingual language skills and practices and not as being failed or insufficient speakers of the TL as was traditionally the case under the monolingual principle (see Howatt, 1984).

One of these unique language practices with which both bilingual and emergent bilingual speakers engage is translanguaging. The term translanguaging has become increasingly popular in research on bilingualism in 
recent years (see, e.g., Canagarajah, 2011; Creese \& Blackledge, 2010; García \& Wei, 2014; Hornberger \& Link, 2012). Translanguaging was originally a term used in reference to the "planned and systematic use of two languages for teaching and learning inside the same lesson" (Lewis, Jones, \& Baker, 2012, p. 643), whereby the languages of classroom input and output were alternated to promote bilingualism in Welsh education programmes. The concept has since been expanded upon to include the naturally occurring languaging practices of bilingual speakers who transcend the systems in their linguistic repertoires. Under this perspective, García (2009) defined translanguaging as the "multiple discursive practices in which bilinguals engage in order to make sense of their bilingual worlds" (p. 45, emphasis in original). A key idea within this notion is that the boundaries separating languages are transient and a construction of the nation-state (see Makoni \& Pennycook, 2007). These "named languages" (e.g., English, Japanese, French, Spanish) are thought to be comprised of linguistic features that belong to a single, expanded linguistic system. Speakers then draw upon features that correspond to a certain "named language" to communicate relevant to given contexts.

Translanguaging, therefore, differs greatly from the simple concept of L1 and L2 use in the FL classroom. The notion of L1 vs. L2 use treats learners' languages as separate entities between which little to no interaction occurs. In a classroom setting, this may involve having learners translate a vocabulary list or reading passage from Japanese to English, or vice versa. Translanguaging, on the other hand, allows for the natural integration and use of all languages in a learner's linguistic system when fit to do so. For example, teachers may allow learners to plan an essay in their language of choice before writing it in English or to engage in a topical discussion in one language before presenting back to the class in English. In such cases, the teacher is not required to understand the language with which learners engage but instead gives control to the students and evaluates the final output in English. For this reason, translanguaging is available to all teachers in bilingual, multilingual, and monolingual classrooms as a tool to help leverage their students' bilingualism, which could be at a whole-class or an individual student level.

Under a translanguaging approach, L2 learners are not considered to be acquiring a new additional language, but are instead adding to the integrated linguistic system of which their native language, and any additional languages, are already a part. In ESL and EFL learning, then, all of the languages in a learner's repertoire are encouraged and utilised in the classroom for 
the purpose of developing the weaker TL (see Baker, 2011). Furthermore, because translanguaging allows learners to engage all of the systems in their linguistic repertoire, learners are able to break free of traditional acts of language separation and, in doing so, establish identity positions (Creese \& Blackledge, 2010) in relation to language learning to make meaning and to learn. This is particularly relevant in the tertiary-level EFL education in Japan as we look at MEXT's Top Global University Project supporting the internationalisation of select universities throughout the country. McKinley (2018) discussed the required shift to treat Japanese tertiary students as users of English instead of learners of English. In doing so, we would also see a change from teaching English as a foreign language to teaching English as a global language, in which use of the L1 is seen as a bilingual resource at the learners' (and by extension, the teacher's) disposal, and learners' language abilities are not tested against native-speaker norms. A bilingual translanguaging approach has the potential to help this paradigm shift in the Japanese EFL context.

\section{Methodology}

The present study was aimed at answering the following two research questions:

RQ1. To what extent and for what functions do teachers and students employ Japanese in the EFL classroom?

RQ2. What are the opinions of teachers and students regarding the potential for a translanguaging approach to EFL education in Japan?

\section{Participants}

The participants in the present study were 373 tertiary-level Japanese students of EFL $(M=224, F=149)$. The vast majority of the participants were aged between 18 and 20 (90.4\%), 7.0\% between 21 and 23, 1.6\% between 24 and 26 , and $1.0 \%$ over 27 . All students were native Japanese speakers. They had been studying EFL for a mean average of 7.6 years. Of the participants, $20.9 \%$ had experience studying abroad in countries such as America, Australia, Canada, England, the Philippines, and Singapore for an average of 16.9 weeks. Most (83.4\%) were from private universities; $13.3 \%$ were from national universities; $2.3 \%$ were from public universities; and 1\% were from other tertiary institutions including junior colleges. The level at which students were studying EFL courses varied: Most were studying at the lower intermediate level (29.8\%), followed by beginner $(26.4 \%)$, intermediate 
(18.1\%), upper intermediate (15.7\%), and advanced (10.0\%). The most common types of EFL classes the students were undertaking were general English (69.9\%), English conversation (60.9\%), English reading (58.2\%), English listening (51.8\%), and English grammar (40.1\%).

261 tertiary-level EFL teacher participants ( $M=189, \mathrm{~F}=66)$ also participated in the study. The participants varied in age but covered a relatively equal spread across the age spectrum from below 25 to above 60 , with an average of 43 years old (see Table 1).

Table 1. Teacher Participant Ages

\begin{tabular}{crr}
\hline Age & $n$ & $\%$ \\
\hline$<25$ & 4 & 1.1 \\
$26-30$ & 10 & 2.8 \\
$31-35$ & 24 & 6.6 \\
$36-40$ & 47 & 13.0 \\
$41-45$ & 48 & 13.3 \\
$46-50$ & 43 & 11.9 \\
$51-55$ & 34 & 9.4 \\
$56-60$ & 33 & 9.1 \\
$>60$ & 18 & 5.2 \\
\hline
\end{tabular}

The majority of the teacher participants (67.9\%) were native English speakers; $26.3 \%$ were native Japanese speakers; and 5.8\% were native speakers of other languages including French, German, Romanian, Russian, Filipino, Dutch, and Finnish. Of the 193 nonnative Japanese speakers, 46.3\% claimed to speak Japanese fluently. A further $30.9 \%$ claimed they could get by comfortably in Japanese; $16.5 \%$ could hold a basic conversation in Japanese; and $6.2 \%$ claimed they could understand some things but could not converse well. No participants claimed to have no proficiency in Japanese. The teacher participants had been teaching EFL in Japan for between 1 and 43 years, for an average of 13.6 years. Most (63\%) taught at private universities, 17.5\% at public universities, $13.6 \%$ at national universities throughout Japan, and $5.9 \%$ at other tertiary-level institution types including junior colleges. The participating teachers taught various English classes, the most common five of which were general English (59.2\%), English reading (43.5\%), English 
conversation (42.3\%), English writing (39.2\%), and English for academic purposes (EAP; $28.1 \%$ ). The majority of teachers taught at the intermediate level (63.8\%), followed by lower intermediate (58.1\%), upper intermediate (51.5\%), advanced (32.3\%), and beginner (31.9\%). Some teachers taught at multiple levels, which are included in these totals.

\section{Procedure}

Two separate questionnaires (one teacher version and one student version: Appendix A and B, respectively) were devised by the researcher and posted on the Internet, where they could be easily distributed to participants via an online system. An appeal for participation in the project was made to English language educators currently employed at tertiary level institutions throughout all 47 prefectures in Japan and to their EFL students to fill out the respective questionnaires. The researcher contacted teachers directly via email and also posted on online forums. Each appeal message contained two links to separate online questionnaires: the teachers' version and the students' version. An appeal was made in the message for teachers to forward the student questionnaire to their students. The researcher did not actively seek student participants due to the logistical difficulties of acquiring students' private email addresses. The responses were collected, and responses in Japanese were translated into English by the researcher for analysis and checked by a Japanese-English bilingual peer.

\section{Questionnaires}

Initial versions of both the teacher and student surveys were piloted with a small group of students and instructors in order to refine each accordingly. Based on the subsequent comments, changes were made to the wording of several items, and some items, which were determined to provide little information, were deleted altogether. The resulting student and teacher questionnaires (each of 32 items) were split into four major sections. The first section sought basic demographic information. Sections 2 and 3 were designed to help answer the first research question: The second section focused on the teachers' use of Japanese, and the third section focused on the students' use of the Japanese in the EFL class.

The fourth section was designed to help answer the second research question, introducing the concept of translanguaging. In this section, the participants were provided with the following brief explanatory definition of translanguaging in both English and Japanese as a reference. This definition 
was derived by the researcher based on previously established definitions and scholarly works on the topic. It was felt that this definition provided a brief look at translanguaging from both a theoretical and classroom-based perspective to provide an overview of the concept as a whole:

Translanguaging is a developing concept in which the deliberate and systematic use of two "languages" is encouraged for education and learning purposes. Translanguaging views all of the "languages" in a speaker's linguistic repertoire as belonging to a single integrated system, whereby speakers select and use the most suitable elements of each language for communicative use in a given context. Second language learners are not considered to be acquiring a new second language, but adding to the integrated linguistic system of which their first language is already a part. In second language learning, then, an important concept within a translanguaging approach is the idea that both learners' first and the target language are encouraged and utilised in the classroom for the purpose of developing the weaker target language.

「トランスランゲージング」(translanguaging)とは、授業の中での教育 と学習に対する計画的、尚且つ構造的な言語使用の概念である。 トランスランゲージングでは自分の言語レパートリー全体を一つの集 合体と見て、そこからその場のコミュニケーションに最適な言語要素 を選んで使う。そして、第二言語の学習者は言語を新しく習得するの ではなく、第一言語が既に属している統合された言語システムに加え る。従って、トランスランゲージングを用いた第二言語の習得では、学 習者の第一言語と対象言語の両方を使用すること、そしてそれが授 業の中で奨励されて利用されることが大切である。

The participants were then asked questions concerning whether a translanguaging approach is something they would be willing to try in their EFL classroom and for explanations as to their answers.

\section{Analysis}

The data analysis for both questionnaires was twofold. First, closed-ended quantitative questions were coded by converting each response into a numerical score corresponding to a list of predetermined variables, which were entered into SPSS (Version 23) for a multifaceted analysis. A descriptive analysis was used to determine the frequencies, percentages, and means of 
the data for the responses to each question. The short-answer open-ended qualitative questions underwent inferential analysis with subjective interpretation by the researcher. The responses to each open-ended question were categorised according to emerging themes and analysed through content analysis relevant to the overall purpose of the study. A combination of quantitative statistical analysis and qualitative interpretation was used because, according to Cohen, Manion, and Morrison (2000), it provides the researcher with the "freedom to fuse measurement with opinion, quantity and quality" (p. 253), adding a more illustrative dimension to the overall data analysis. A reliability analysis for both questionnaires was also conducted using SPSS, and Cronbach's alpha coefficient was determined to be .80 for the teacher survey and .85 for the student survey, suggesting a satisfactory reliability overall.

\section{Findings}

\section{Teachers' Use of Japanese}

To determine how often Japanese is used by EFL teachers, the student participants were asked to report on the frequency of their teachers' use, and the teachers were asked to self-report on their own use of Japanese in the EFL classroom. The results are presented in Figure 1.

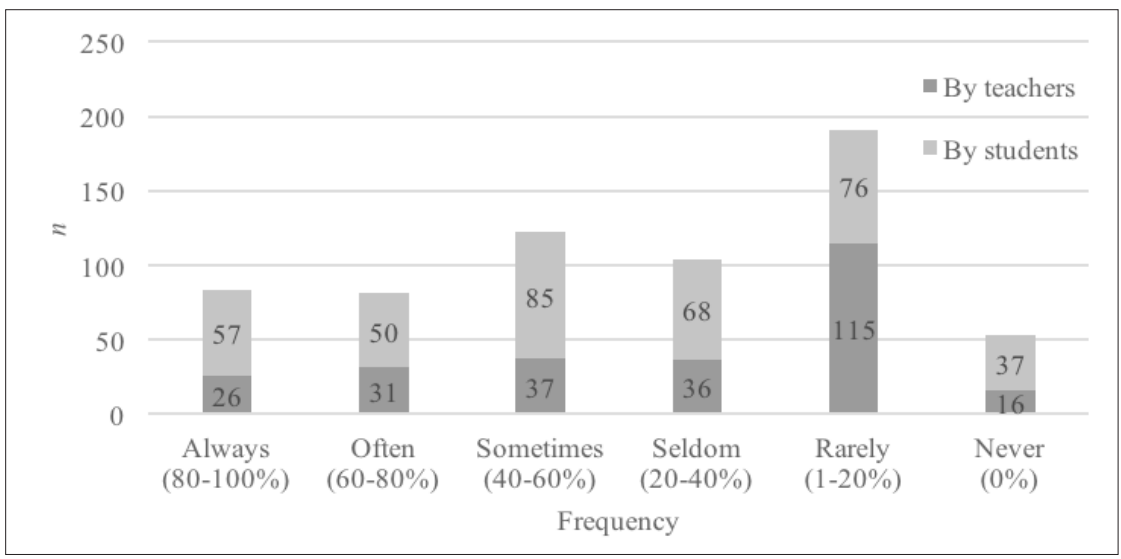

Figure 1. Student and teacher reports of the frequency with which teachers use Japanese. Student $n=373$; Teacher $n=261$.

Although nearly one third of the participants reported the teachers' use of Japanese to be rare (1-20\% of the time), it is interesting to note the dif- 
ference between the reports from students and teachers for this category (a difference of $23.7 \%$ ), which may be due to problems associated with selfreporting by the teacher participants. The student and teacher participants were then asked to report on the functions for which EFL teachers employ Japanese in the English classroom (see Figure 2).

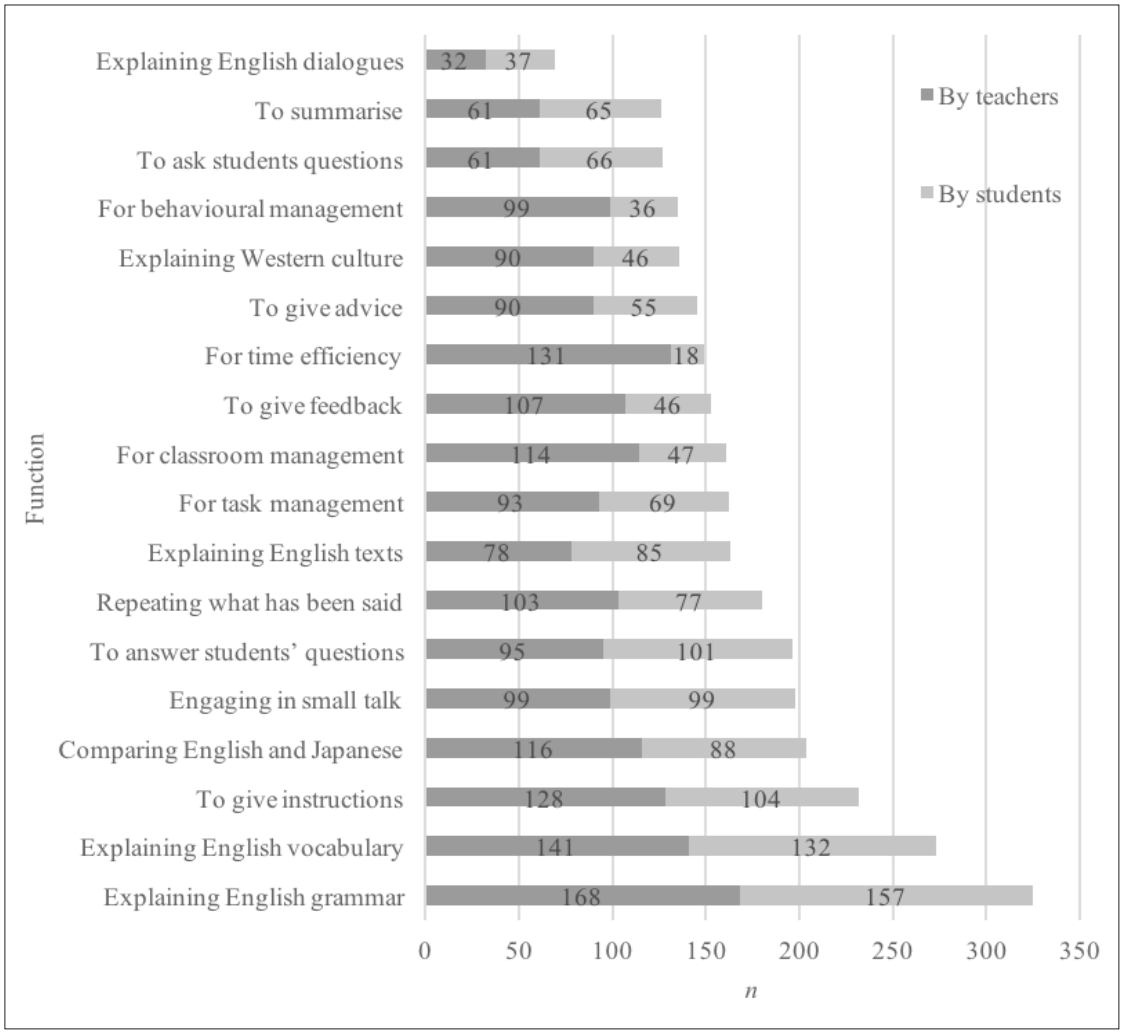

Figure 2. Student and teacher reports of the functions for which teachers use Japanese. More than one response was possible. Student $n=373$; Teacher $n=261$.

The three most common functions were reported to be employed by more than one third of all teachers, and the 10 most common functions were reportedly used by one quarter. Vast differences can be seen between what the teachers and students reported in some instances, particularly for the functions of classroom management (a difference of 31.1\%), behavioural management (28.2\%), and time efficiency (45.4\%). These differences may 
be attributed to the fact that such tasks are generally the sole responsibility of the teacher, and thus the student participants may not have recognised their enactment because they themselves are not required to use these functions.

\section{Students' Use of Japanese}

Both the student and teacher participants were asked to report on how often students use Japanese in the EFL classroom. The results are presented in Figure 3.

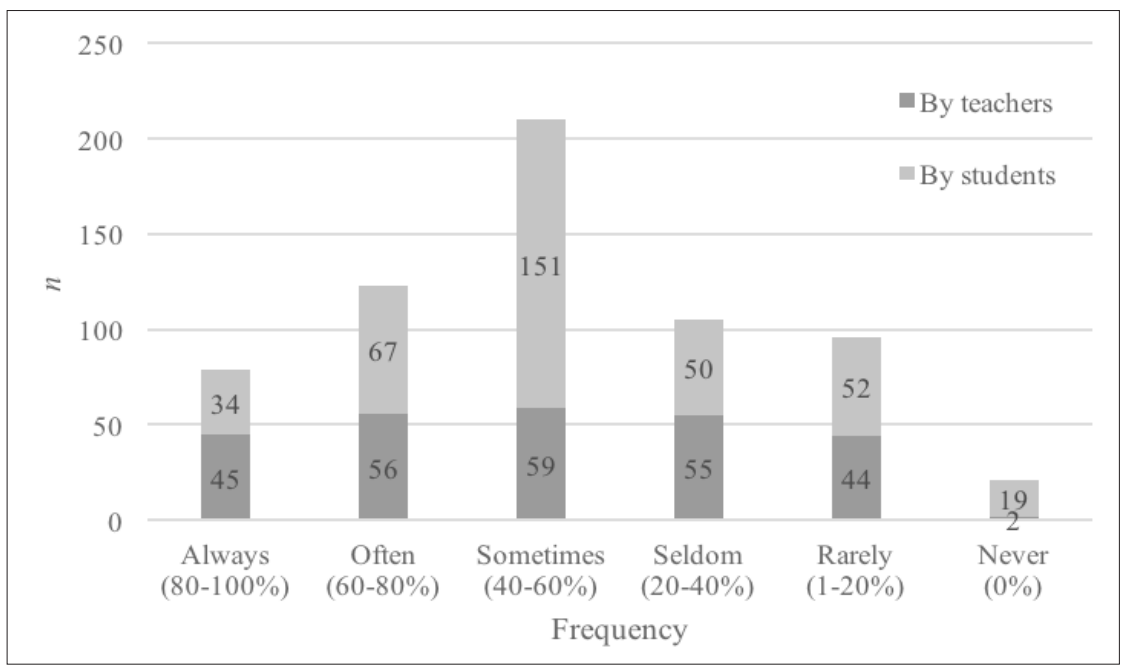

Figure 3. Student and teacher reports of the frequency with which students use Japanese in the EFL classroom. Student $n=373$; Teacher $n=261$.

One third of all students reported or were reported as using Japanese some of the time (40-60\%), with close to another third of respondents $(31.9 \%)$ claiming students' use of Japanese to be more than $60 \%$. The functions for which students most commonly employ Japanese in the EFL classroom, according to both categories of participants, are presented in Figure 4. 


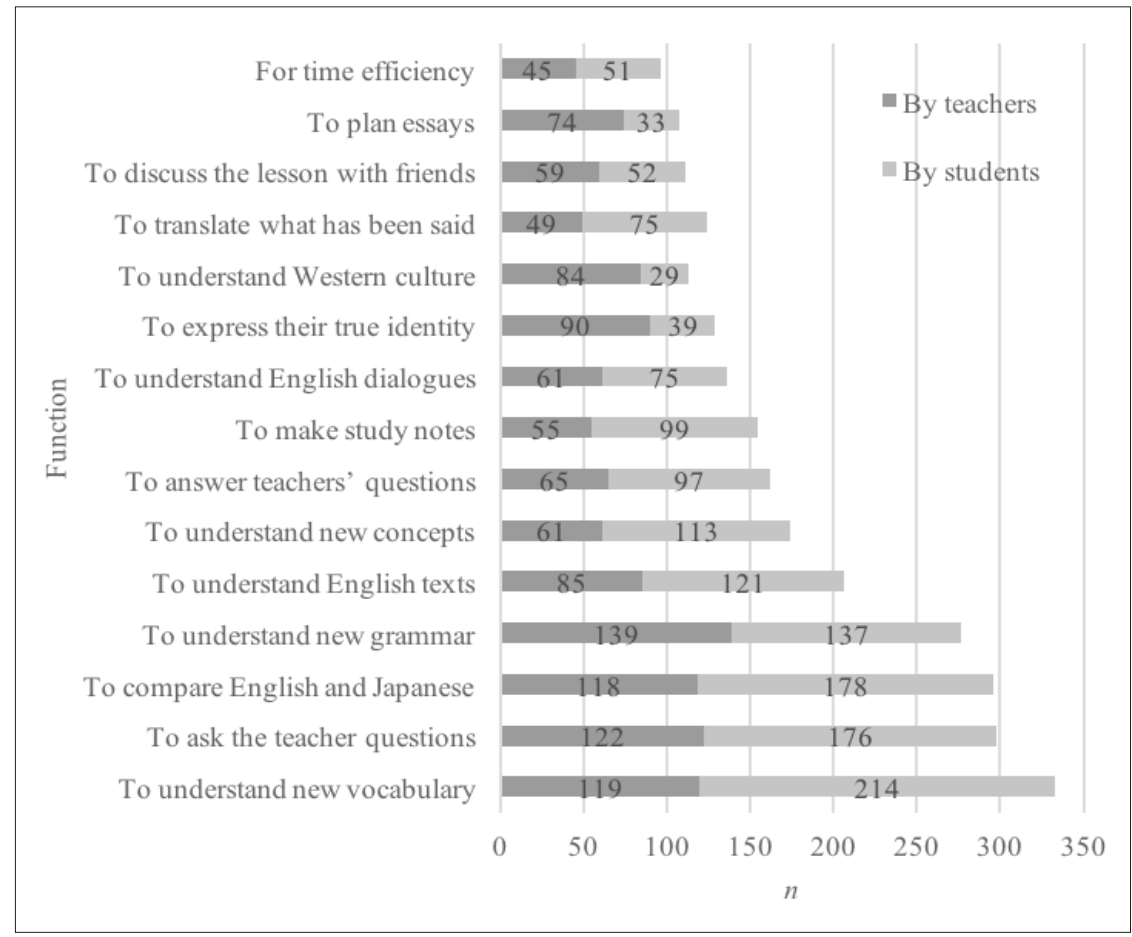

Figure 4. Student and teacher reports of the functions for which students use Japanese. More than one response was possible. Student $n=373$; Teacher $n=261$.

The five most common functions for which students employ Japanese were reported to be employed by one third of all EFL students. Remarkably similar reports can be seen from both the students and teachers for almost all functions, with the exception of to express their true identities and to understand Western culture. Such low frequencies from the students regarding their expression of identity through the use of Japanese may suggest that few see Japanese, or language in general, as contributing to their overall identities. It may also be attributed to the fact that few see a connection between language use and identity in general or language as a means through to which to understand content indirectly related to language such as culture. 


\section{Bilingualism in FL Education}

The student and teacher participants were asked the extent to which they agreed with the idea that FL education should be thought of as bilingual education. This question was included to address the fact that the term bilingual education can be interpreted in several different ways, and it was thus important to determine where Japanese EFL students and teachers stood on the matter. A relatively equal ratio of student to teacher opinions was observed for each level of agreement, except for level 3, which an overwhelming number of teachers chose compared to the smallest number of students. The results are presented in Figure 5.

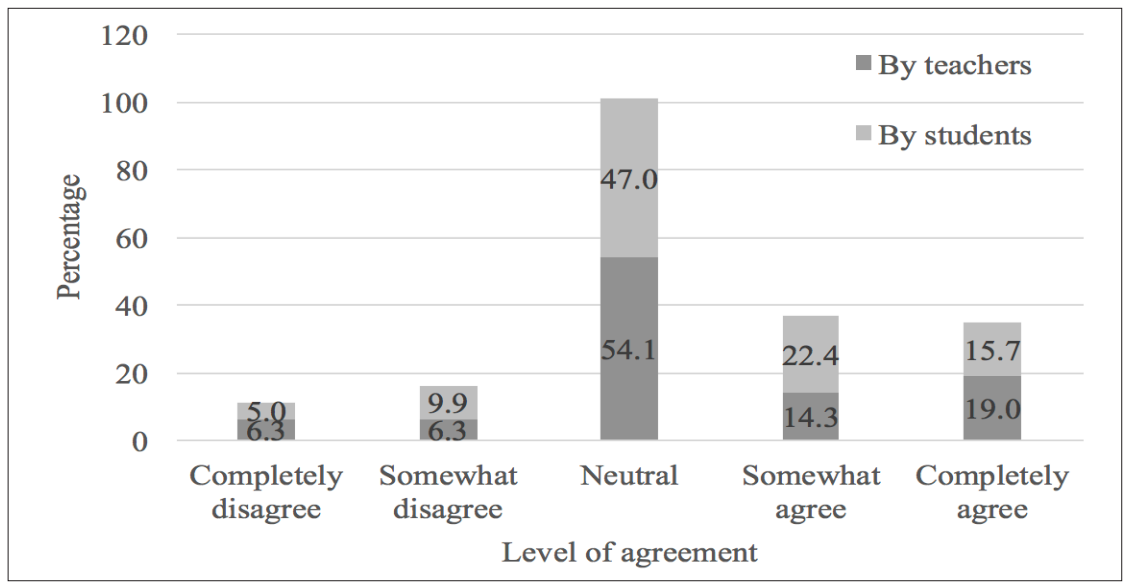

Figure 5. Percentages of agreement among teachers and students with the idea that FL education should be thought of as bilingual education. Student $n=373$; Teacher $n=261$.

Although the majority of students and teachers took the middle ground and reported a 3 for their agreement towards the idea, more subsequently opted for a higher agreement than a lower agreement. A total of $36.7 \%$ and $34.7 \%$ answered 4 and 5 respectively, compared to just $11.3 \%$ and $16.2 \%$ who answered 1 and 2 respectively. This suggests that, at least among those surveyed, more EFL teachers and students in Japan are accepting of the idea that FL education is a form of bilingual education than are not, which provides support for the notion of introducing bilingual pedagogies, such as translanguaging, into mainstream EFL education in the Japanese context. 
However, the participants were then asked where the students would place themselves and where the teachers would place their students on a 10-point scale for level of bilingualism (where 1 meant not at all bilingual and 10 meant bilingual). The results are presented in Figure 6.

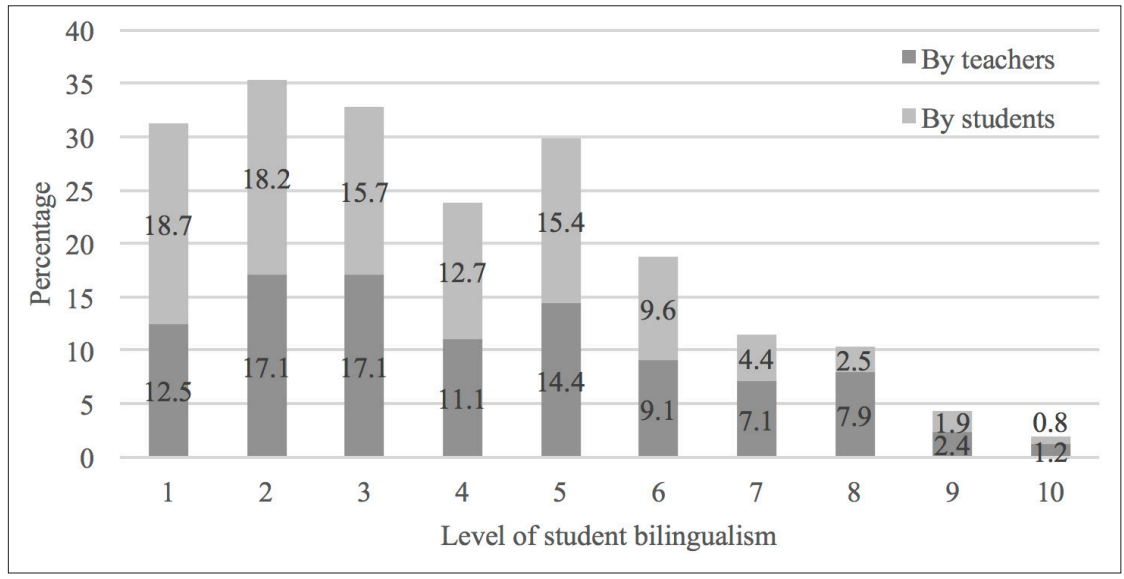

Figure 6. Percentage of teachers and students reporting to view students as bilingual on a 10-point scale, where 1 represents not at all bilingual and 10 represents bilingual. Student $n=373$; Teacher $n=261$.

The majority of students and teachers (76.5\%) judged EFL learners to be 5 or below on the bilingual scale, compared to just $23.4 \%$ who rated them above 5. On the one hand, this view could be seen as in opposition to the views presented in Figure 1 concerning the bilingual nature of FL education, but what this also suggests is that, despite perceiving FL education to be a form of bilingual education, the students educated in Japan are not thought of as fully bilingual. This is perhaps due to their reported low levels of English, the manner in which they are taught, and/or the manner in which they study and learn as individuals.

When asked why they thought this to be the case, the teacher participants took two stances. Those who disagreed with students' bilingualism (i.e., Levels 1-4 on the bilingualism scale) focused on students' lack of English abilities (grammar, vocabulary, collocational knowledge, pronunciation, etc.). However, those who recognised their students' bilingualism (i.e., Levels 6-10 on the bilingualism scale) focused on the flexibility that the term bilingualism allows; for example, one teacher commented, "Being bilingual means being able to use two languages, not necessarily fluently. My students 
can do this." When asked the same question, the student participants also focused on their inability to speak or think in English. One interesting comment focused on the relationship between the use of English and bilingualism: “英語は, 何かを学ぶための手段だと考えているので, バイリンガルと認識して いないため (Because I think English is a means to learn something, I don't recognise it as bilingualism)."

The majority of the teacher participants (46.1\%) had never heard of a translanguaging approach to language education; $16.4 \%$ knew very little about it, followed by $14.1 \%$ who had heard of it, but do not know much about it. Only $16 \%$ claimed to know a little about it, compared to just $7.4 \%$ who claimed to know it very well. In other words, $76.6 \%$ of the teacher participants may have been suggesting that they did not know enough about translanguaging to engage in its practices without training. Interestingly, $56.0 \%$ of the teacher participants claimed they would like to know more about translanguaging, $24.1 \%$ expressed that they might like to learn more, and just $19.8 \%$ claimed they would not like to know more. The fact that almost $45 \%$ of the teacher participants were not openly eager to learn more suggests the potential for noninterest in translanguaging, which may be due to factors such as satisfaction with current methods, a lack of desire for L1 use in the classroom, institutional policy restrictions, and/or a lack of understanding or education regarding a translanguaging approach. Future research would be required to determine the exact reasons for this.

When asked whether they would be willing to try a translanguaging approach to EFL education, the teacher and student participants answered as shown in Figure 7. Many of the teachers' comments in favour of attempting a translanguaging approach centered on concepts such as "I'm always open to trying a new approach" and "I would try anything to improve my teaching." Some commented on similarities between translanguaging and their current approach and reported a desire to learn more about how better to structure it. Others referred to the motivational benefit translanguaging may have for their students who are insecure about their English abilities.

On the other hand, those teachers who were against attempting a translanguaging approach made such comments as "I don't know enough about it yet" and "I don't quite support the idea." Reasons provided against the implementation of translanguaging included teachers' concern that the use of Japanese would dominate students' English use, satisfaction with their current pedagogical approach, and certain institution policy restrictions against the use of the L1. 


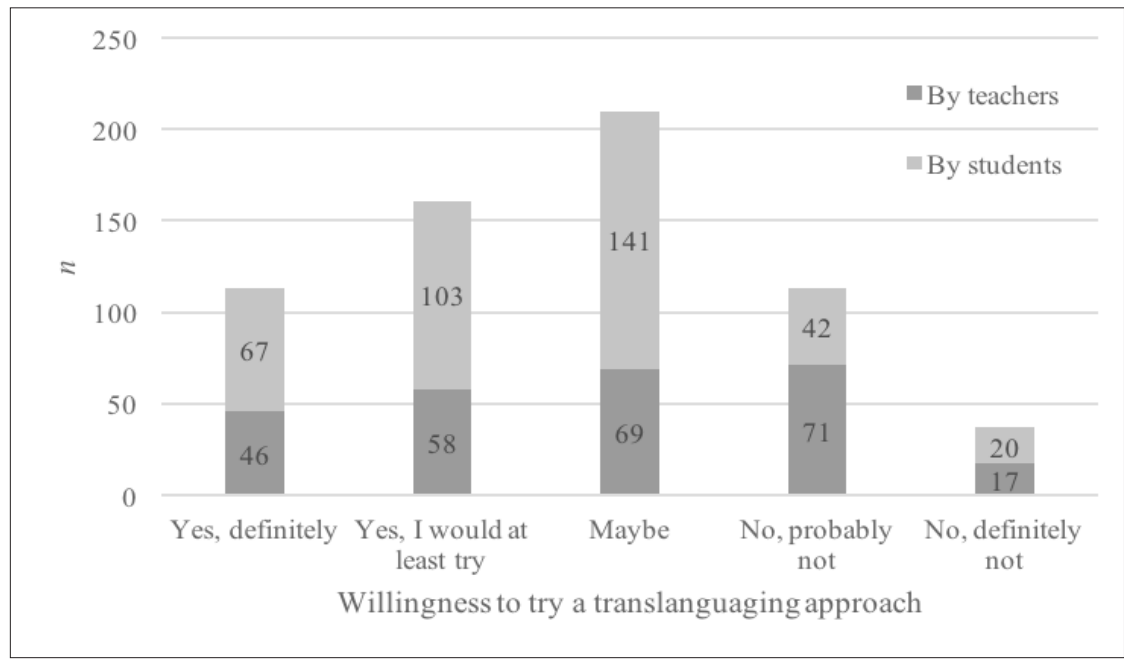

Figure 7. Student and teacher reports of their willingness to try a translanguaging approach to EFL education. Student $n=373$; Teacher $n=261$.

However, some teachers seemed to have misunderstood the concept altogether, as can be seen in comments such as "it seems that the teacher must know the students' L1 very well to try this, and my Japanese isn't good enough" and "I occasionally teach students in multilingual classroom. The approach wouldn't work out in that setting."

Those student participants who were in favour of trying a translanguaging approach to EFL education provided comments with relatively less substance than their teachers, simply stating that translanguaging would allow them to better learn or understand English without any indication of how, suggesting a relatively shallow understanding of the benefits of translanguaging overall. That said, two particularly interesting comments were very much in line with some of the underlying foundations of a translanguaging approach: “完璧な英語を使わないといけないという考え方が嫌いだから (Because I hate the idea that you have to use perfect English)” and “良いことだと思いま す。トランスランゲージを行うことで、言語能力が第一言語と第二言語のどちらかに偏 らないと思うからです (I think it is good. Because I think that by using translanguaging, one's language ability does not show bias to either the first or second language)." These comments highlight the noncompetitive linguistic freedom that a translanguaging approach can afford, suggesting a relatively deep understanding of how translanguaging may be of benefit towards the 
development of EFL learners' overall bilingualism. Such comments, however, were not common.

On the other hand, those student participants who were against translanguaging commented that the approach would lead to an excessive use of Japanese and that because learners already have few chances to speak English, they want to speak English in class. One particular comment reflected a misunderstanding of translanguaging similar to that of some of the teacher participants: “日本人と違う母国語を持つ人がいる場合その人が不利にな る (In situations where there are Japanese and people with different mother tongues, those people are at a disadvantage)." Once again, these comments shed light on the general misunderstandings surrounding the concept of translanguaging and the associated need for comprehensive training and/or education for both teachers and students alike before it can be successfully introduced to EFL education in Japan.

\section{Discussion}

Analysis of the data answers the first research question: "To what extent and to what purposes do teachers and students employ Japanese in the EFL classroom?" Despite the government policies emphasising a predominantly English-based classroom, it is clear that Japanese is employed in the EFL classroom in Japan by both the teachers and students to varying degrees. Very small margins of differences were reported between the mean percentages of Japanese usage by both the students and teachers in most categories, suggesting a constant and reliable response overall. The high-level reporting of a "rare" usage by the teachers may be due to problems associated with self-reporting bias, whereby the teachers may have claimed their use of Japanese to be lower because of preconceptions that use of the L1 is undesirable in L2 learning.

Three out of the top five functions for which students were reported to employ Japanese were the same as those for which teachers were reported to use Japanese. Close to one half of all participants who reported to employ Japanese are said to employ it for the functions of better understanding or teaching grammar and vocabulary and to compare English and Japanese. The other functions comprising the top five most common (for both teachers and students) have been noted by researchers in the past, including to give instructions (Tang, 2002) and to engage in small talk with students (Littlewood \& Yu, 2011) by teachers and to ask the teacher questions (Norman, 2008) and to understand English texts (Turnbull \& Sweetnam Evans, 2017) by students. However, it seems that many of the functions for which 
Japanese is employed in EFL education in Japan may, in fact, perpetuate the monolingual principle (see Howatt, 1984), in which the two languages are viewed as separate entities in the learners' minds and the learners themselves are regarded as double monolinguals rather than multicompetent bilinguals (Cook, 1999).

The manner in which Japanese is currently employed for various functions in the EFL classroom in Japan is what is important as we look towards the possibility of introducing a translanguaging approach to help improve the current state of EFL learners' English abilities. For example, a simple vocabulary translation task from one language to the other is not considered within the beneficial framework of a translanguaging approach (see García \& Wei, 2014). Active employment of both languages is required if learners are to become competent bilingual speakers through translingual practices. The commonly reported teachers' function of employing Japanese to engage in small talk with their students may teach learners how to effectively engage in fluid bilingual languaging practices if the teacher is able to do so. The fact that all 261 teachers reported themselves to hold some proficiency in Japanese, with over 3 out of 4 claiming to have a relatively high proficiency, suggests they may be able to engage in fluid bilingual practices, but even in such cases, a translanguaging approach is likely to fail in Japan if both the students and teachers are unwilling to accept its implementation. This, then, answers the second research question: "What are the opinions of teachers and students alike regarding the potential for a translanguaging approach to EFL education in Japan?"

A much larger number of the participants were in favour of the idea of FL learning as bilingual education than those who were not, providing some support towards the potential of introducing bilingual pedagogies, such as translanguaging, into mainstream EFL education in Japan. That said, less support was given for the notion of EFL students being bilingual despite research in favour of the claim (see Turnbull, 2016), although it was noted that some students did recognise the noncompetitive nature that a translanguaging approach can afford: one that may help to alleviate the hegemonic perceptions that continue to surround the English language in the minds of some Japanese (see McVeigh, 2002).

Both the teacher and student participants who were against the implementation of a translanguaging approach commented on their concern that reliance on Japanese would increase in the classroom and the use of English would decrease. This has been questioned by some scholars (see, e.g., Gaebler, 2014), who have found that learners generally recognise the 
importance of using the TL in the classroom and thus show no reluctance to do so when given the opportunity to also use their L1. Others questioned the use of the L1 in general. Indeed, native speakerism (see Holliday, 2006) as reflected in policy, institutional practice, and teacher cognition is a hurdle that must be overcome for a translanguaging approach to take hold in Japan. Some students and teachers may see the use of the mother tongue as a deficit in EFL education, believing the notion that English is best learnt in Englishonly environments. Such teachers may thus be hesitant to allow learners to engage in bilingual languaging strategies that allow such practices; however, this issue can be overcome with proper education and training regarding the benefits of mother tongue inclusion and how to engage in approaches such as translanguaging to leverage students' bilingualism overall.

Some student participants also commented on the lack of opportunities they have to speak English and that a translanguaging approach might minimise that further. However, it must be pointed out that translanguaging does not promote the use of one language over the other but rather works to break down the hierarchies between languages to provide an equal opportunity for the use of each in a noncompetitive environment. Further misunderstandings towards the concept of translanguaging were also reported, such as teachers needing to know the students' mother tongue well and the impossibility of implementing translanguaging in a multilingual classroom with learners of different mother tongues. In fact, it is not a requirement for the teacher to speak the students' native language nor for the students to all share the same native language (as is the case in multilingual classrooms) under a translanguaging approach. So long as the teacher is willing to relinquish some power and authority to the students so that they may employ their home language themselves to help develop the weaker TL, a translanguaging space can be created in any classroom, regardless of the students or teachers involved (see García \& Wei, 2014).

\section{Conclusion}

The purpose of the present study was to investigate the theoretical potential of introducing a translanguaging approach to EFL education in Japan to improve the reportedly low standards of students' English abilities and to bridge the gap between government policy and actual classroom practice. The findings show that, although Japanese is used to various degrees and for various functions by both teachers and students in EFL education in Japan and the bilingual nature of EFL education was acknowledged to some extent, the emergent bilingual status of FL learners was less com- 
monly recognised, which may prevent the successful implementation of a translanguaging approach.

Due to the limited structure of the survey employed in the present study, it is acknowledged that the participants were only provided with a brief definition of what a translanguaging approach entails without concrete evidence (although a link was provided that directed them to more information), and this may have affected their views towards the approach either way. It must also be pointed out that the definition provided was largely academically based, providing few practical examples upon which participants could ground the theoretical explanation. In the case of the learner participants, this definition may have exceeded their understanding and thus weakened the validity or applicability of their responses. Furthermore, it is acknowledged that, due to the style of the questionnaire, it is possible that some participants may have understood the questionnaire to be a promotion of translanguaging and thus answered favourably in an attempt to placate the interests or wishes of the researcher.

However, based on the reported use of Japanese in the English classroom and the conflicts that exist between government policy and classroom practices, there certainly does appear to be a theoretical space for a translanguaging approach to EFL education in Japan, and its introduction would not be overly difficult. A small change in the government's FL policies is the first step. Based on the results of the present study, it would seem as though the use of, and preference for, the L1 is still high in the Japanese EFL context. This suggests that perhaps the jump from a Japanese-dominated EFL classroom to an immersive, predominantly English-based classroom is too large for a society that has, for so long now, relied on their native language in the learning of an FL. An intermedial step is required to bridge the overwhelming gap between MEXT's policy ideals and the realities of the current Japanese EFL classroom, and a translanguaging approach is one such pedagogy that could provide that. Future research would look at the potential for a translanguaging approach from an empirical and, ideally, longitudinal perspective, examining the actual in-class effects of the approach in action. Furthermore, although the present study centered on the tertiary level, that is certainly not to say the findings do not apply to junior and senior high school in which the use of the L1 is more frequent. Future research would also examine the empirical effects of a translanguaging approach across various institutional levels to gain a broader perspective of how the approach may affect EFL education in Japan on the whole. 
That said, speaking from a theoretical perspective, the manner in which Japanese is currently employed for various functions could be strategically morphed into a translanguaging approach if some important conditions can be filled. First, a change in the mindset surrounding FL education and, in particular, FL learners is required, so that the bilingual nature of both are recognised. In doing so, the manner in which Japanese is currently employed could shift towards more translingual practices that involve the active and strategic use of learners' complete linguistic repertoires to develop the weaker TL. The success of this would depend largely on how well teachers and students alike are willing to accept it and would be further influenced by the level of training and education provided to both parties. The present study suggests that some teachers and students are at least willing to attempt a translanguaging approach in Japan; sufficient training for teachers, and the subsequent in-class training to be provided to students, would help to alleviate the misconceptions and misunderstandings surrounding the notion of translanguaging that were found in this study.

Blake Turnbull is a PhD student at Kyoto University and part-time English instructor at Ritsumeikan University and Kyoto University of Foreign Studies. His research interests are in ELT, bilingualism, and translanguaging.

\section{References}

Aoki, M. (2017, April 6). Japan's latest English-proficiency scores disappoint. The Japan Times. Retrieved from https://www.japantimes.co.jp

Auerbach, E. R. (1993). Reexamining English only in the ESL classroom. TESOL Quarterly, 27, 9-32. https://doi.org/10.2307/3586949

Baker, C. (2011). Foundations of bilingual education and bilingualism (5th ed.). Bristol, England: Multilingual Matters.

Bradford, A., \& Brown, H. (Eds.). (2018). English-medium instruction in Japanese higher education. Bristol, England: Multilingual Matters.

Brooks-Lewis, K. A. (2009). Adult learners' perceptions of the incorporation of their L1 in foreign language teaching and learning. Applied Linguistics, 30, 216-235. https://doi.org/10.1093/applin/amn051

Burden, P., \& Stribling, P. (2003). Attitude change toward mother tongue usage in conversation class. The Language Teacher, 27(1), 3-7. Retrieved from http://www.jalt-publications.org/tlt/archive 
Butler, Y. G., \& Iino, M. (2005). Current Japanese reforms in English language education: The 2003 "action plan." Language Policy, 4, 25-45. https://doi.org/10.1007/s10993-004-6563-5

Butzkamm, W. (2011). Why make them crawl if they can walk? Teaching with mother tongue support. RELC Journal, 42, 379-391. https://doi.org/10.1177/0033688211419830

Canagarajah, S. (2011). Translanguaging in the classroom: Emerging issues for research and pedagogy. Applied Linguistics Review, 2, 1-28. https://doi.org/10.1515/9783110239331.1

Carless, D. (2008). Student use of the mother tongue in the task-based classroom. ELT Journal, 62, 331-338. https://doi.org/10.1093/elt/ccm090

Cohen, L., Manion, L., \& Morrison, K. (2000). Research methods in education (5th ed.). London, England: Routledge. https://doi.org/10.4324/9780203224342

Cook, V. (1999). Going beyond the native speaker in language teaching. TESOL Quarterly, 33, 185-209. https://doi.org/10.2307/3587717

Cook, V. (2001). Using the first language in the classroom. Canadian Modern Language Review, 57, 402-423. https://doi.org/10.3138/cmlr.57.3.402

Creese, A., \& Blackledge, A. (2010). Translanguaging in the bilingual classroom: A pedagogy for learning and teaching? The Modern Language Journal, 94, 103115. https://doi.org/10.1111/j.1540-4781.2009.00986.x

Cummins, J. (2007). Rethinking monolingual instructional strategies in multilingual classrooms. Canadian Journal of Applied Linguistics, 10, 221-240.

Gaebler, P. (2014). L1 use in FL classrooms: Graduate students' and professors' perceptions of English use in foreign language courses. The CATESOL Journal, 25(1), 66-94.

García, O. (2009). Bilingual education in the 21st century: A global perspective. Malden, MA: Wiley \& Blackwell.

García, O., \& Wei, L. (2014). Translanguaging: Language, bilingualism and education. Basingstoke, England: Palgrave Macmillan. https://doi.org/10.1057/9781137385765

Hall, G., \& Cook, G. (2012). Own-language use in language teaching and learning. Language Teaching, 45, 271-308. https://doi.org/10.1017/S0261444812000067

Hawkins, S. J. (2015). Perspectives: Guilt, missed opportunities, and false role models: A look at perceptions and use of the first language in English teaching in Japan. JALT Journal, 37, 29-42.

Retrieved from http://www.jalt-publications.org/jj/archive 
Hobbs, V., Matsuo, A., \& Payne, M. (2010). Code-switching in Japanese language classrooms: An exploratory investigation of native vs. non-native speaker teacher practice. Linguistics and Education, 21(1), 44-59. https://doi.org/10.1016/j.linged.2009.12.004

Holliday, A. (2006). Native-speakerism. ELT Journal, 60, 385-387. https://doi.org/10.1093/elt/ccl030

Hornberger, N. H., \& Link, H. (2012). Translanguaging and transnational literacies in multilingual classrooms: A biliteracy lens. International Journal of Bilingual Education and Bilingualism, 15, 261-278. https://doi.org/10.1080/13670050.2012.658016

Howatt, A. (1984). A history of English language teaching. Oxford, England: Oxford University Press.

Lewis, G., Jones, B., \& Baker, C. (2012). Translanguaging: Origins and development from school to street and beyond. Educational Research and Evaluation, 18, 641-654. https://doi.org/10.1080/13803611.2012.718488

Littlewood, W. (2007). Communicative and task-based language teaching in East Asian classrooms. Language Teaching, 40, 243-249. https://doi.org/10.1017/S0261444807004363

Littlewood, W., \& Yu, B. (2011). First language and target language in the foreign language classroom. Language Teaching, 44, 64-77. https://doi.org/10.1017/S0261444809990310

Makoni, S., \& Pennycook, A. (2007). Disinventing and reconstituting languages. Clevedon, England: Multilingual Matters.

McKinley, J. (2018). Making the EFL to ELF transition in English-medium instruction at a global traction university. In A. Bradford, \& H. Brown (Eds.), Englishmedium instruction in Japanese higher education (pp. 238-249). Bristol, England: Multilingual Matters.

McVeigh, B. J. (2002). Japanese higher education as myth. New York, NY: M. E. Sharpe.

MEXT. (2003). Regarding the establishment of an action plan to cultivate "Japanese with English abilities." Retrieved from http://web.archive.org/ web/20030810151415/http://www.mext.go.jp/english/topics/03072801.htm

MEXT. (2011). The revisions of the courses of study for elementary and secondary schools. Retrieved from http://www.mext.go.jp/en/policy/education/elsec/ title02/detail02/_icsFiles/afieldfile/2011/03/28/1303755_001.pdf 
MEXT. (2014). English education reform plan corresponding to globalization. Retrieved from http://www.mext.go.jp/en/news/topics/detail/_icsFiles/ afieldfile/2014/01/23/1343591_1.pdf

Norman, J. (2008). Benefits and drawbacks to L1 use in the L2 classroom. In K. Bradford Watts, T. Muller, \& M. Swanson (Eds.), JALT2007 Conference Proceedings. Challenging assumptions: Looking in, looking out, (pp. 691-701). Tokyo: JALT. Retrieved from http://www.jalt-publications.org/proceedings

Saito, H., \& Ebsworth, M. E. (2004). Seeing English language teaching and learning through the eyes of Japanese EFL and ESL students. Foreign Language Annals, 37, 111-124. https://doi.org/10.1111/j.1944-9720.2004.tb02178.x

Samimy, K. K., \& Kobayashi, C. (2004). Toward the development of intercultural communicative competence: Theoretical and pedagogical implications for Japanese English teachers. JALT Journal, 26, 245-261. Retrieved from http:// www.jalt-publications.org/jj/archive

Storch, N., \& Aldosari, A. (2010). Learners' use of first language (Arabic) in pair work in an EFL class. Language Teaching Research, 14, 355-375. https://doi.org/10.1177/1362168810375362

Tang, J. (2002). Using L1 in the English classroom. English Teaching Forum, 40(1), 36-43.

Terauchi, H. (2017). English education at universities in Japan: An overview and some current trends. In E. S. Park \& B. Spolsky (Eds.), English education at the tertiary level in Asia: From policy to practice (pp. 65-83). New York, NY: Routledge.

Turnbull, B. (2016). Reframing foreign language learning as bilingual education: Epistemological changes towards the emergent bilingual. International Journal of Bilingual Education and Bilingualism. http://dx.doi.org/10.1080/13670050.2016.1238866

Turnbull, B. (2018). Examining pre-service ESL teacher beliefs: Perspectives on first language use in the second language classroom. Journal of Second Language Teaching and Research, 6, 50-76.

Turnbull, B., \& Sweetnam Evans, M. (2017). The effects of L1 and L2 group discussions on L2 reading comprehension. Reading in a Foreign Language, 29, 133-154.

Turnbull, M., \& Dailey-O'Cain, J. (Eds.). (2009). First language use in second and foreign language learning. Bristol, England: Multilingual Matters. 
Yavuz, F. (2012). The attitudes of English teachers about the use of L1 in the teaching of L2. Procedia - Social and Behavioral Sciences, 46, 4339-4344. https://doi.org/10.1016/j.sbspro.2012.06.251

\section{Appendix A}

\section{L1 Use in Japanese EFL Education: Teacher Questionnaire}

\section{Section 1: Introduction}

1. What is your gender?
(a) Male
(b) Female

2. To which age group do you belong?
(a) $<25$
(f) $46-50$
(b) $26-30$
(g) $51-55$
(c) $31-35$
(h) $56-60$
(d) $36-40$
(i) $>60$
(e) $41-45$

3. What is your native language?
(a) Japanese (go to Question 4)
(c) Other (go to Question 6)
(b) English (go to Question 6)

4. For how long have you studied English?

5. Have you ever studied overseas? If so, where and for how long

6. Do you speak Japanese?
(a) Yes, fluently
(b) Yes, I can get by comfortably
(c) Yes, I can hold a basic conversation
(d) I can understand some things, but cannot speak very well
(e) No, not at all
(f) Other

7. For how long have you been teaching EFL in Japan?

8. At which type of institution do you currently teach EFL?
(a) Public university
(c) National university
(b) Private university
(d) Other 
9. Which level of English do you currently teach?
(a) Beginner
(d) Upper intermediate
(b) Lower intermediate
(e) Advanced
(c) Intermediate

10. What kind of English class do you currently teach?
(a) General English
(b) English reading
(c) English writing (general)
(d) Academic writing
(e) English for Academic Purposes (EAP)
(f) English for Specific Purposes (ESP)
(g) English conversation
(h) English listening
(i) English grammar
(j) Other

11. What is the main pedagogical approach you choose to employ in your EFL classroom?
(a) Communicative language teaching (CLT)
(b) The Direct Method
(c) Grammar Translation
(d) Immersion
(e) PPP (presentation, practice, production)
(f) No method in particular
(g) Other

\section{Section 2: Teacher's Use of the L1}

12. How often do you utilise your students' first language (L1) in the English classroom?
(a) Always (80-100\% of the time)
(b) Often $(60-80 \%$ of the time)
(c) Sometimes (40-60\% of the time)
(d) Seldom (20-40\% of the time)
(e) Rarely (1-20\% of the time)
(f) Never ( $0 \%$ of the time) 
13. In what situations do you utilise the students' L1?

Explaining English grammar

Explaining English vocabulary

Explaining English texts

Explaining Western culture/ideologies

Explaining English listening passages

Comparing English and Japanese structures

Repeating something in Japanese after saying it first in English

Engaging in small-talk with your students

$\square$ To give instructions

For time efficiency

$\square$ To provide feedback

$\square$ To give students advice on effective studying methods

$\square$ For classroom management (administration, discussing the course, etc.)

$\square$ For behavioural management (discipline, student organisation, etc.)

$\square$ For task management (instructions, ensure comprehension, maintain task flow, etc.)

To ask students questions

To answer students' questions

$\square \quad$ To summarise what has been covered

$\square$ Other

\section{Section 3: Students' Use of the L1}

15. Do you allow your students to utilise their L1 in the EFL classroom?
(a) Yes, often
(d) No, never
(b) Yes, sometimes
(e) Other
(c) No, not really

16. How often do you allow your students to use their L1 in class?
(a) Always (80-100\% of the time)
(b) Often (60-80\% of the time)
(c) Sometimes (40-60\% of the time)
(d) Seldom (20-40\% of the time)
(e) Rarely (1-20\% of the time)
(f) Never ( $0 \%$ of the time) 
17. For what purposes do you allow your students to use their L1? (continue to question 21)

To discuss grammar

To discuss vocabulary

To discuss culture

To understand new concept better

To ask questions to the teacher

To answer questions from the teacher

To compare English and Japanese

To translate what has been said

To plan L2 writing tasks

To aid $\mathrm{L} 2$ reading comprehension

To aid L2 listening comprehension

For time efficiency

$\square$ To discuss the lesson with classmates/friends

$\square \quad$ To make study notes

To allow students to express their true identities

Other

Section 4: A Translanguaging Approach to EFL Education

18. To what extent do you agree with the idea that foreign language education could/should be considered bilingual education?
Not at all (1)
(2)
(3)
(4)
(5) Completely agree

19. Why do you think this?

20. If you were to place your students somewhere along this bilingual continuum, whereby 1 means 'not at all bilingual' and 10 means 'bilingual', in general, where would you place your students?

Not at all bilingual (1) (2) (3) (4) (5) (6) (7) (8) (9) (10) Completely bilingual

21. How much do you know about a 'translanguaging approach' to foreign language education?
(a) I know it very well
(b) I know a little bit about it
(c) I've heard of it, but do not know much about it
(d) I know very little about it
(e) I have never heard of it
(f) Other 
22. Based on the above definition of translanguaging, does it sound like a pedagogical concept you would like to know more about?
(a) Yes, definitely
(d) No, probably not
(b) Yes, a little bit
(e) No, definitely not
(c) Maybe

23. Would you be willing to try out a translanguaging approach to L2 education in your EFL classroom?
(a) Yes, definitely (go to Question 24)
(b) Yes, I would at least try it (go to Question 24)
(c) Maybe (go to Question 24)
(d) No, probably not (go to Question 25)
(e) No, definitely not (go to Question 25)

24. Please explain why you would like to try a translanguaging approach to EFL education in your classroom?

25. Please explain why you would not like to try a translanguaging approach to EFL education in your classroom?

\section{Appendix B}

\section{L1 Use in Japanese EFL Education: Student Questionnaire}

\section{Section 1: Introduction}

1. What is your gender? 性別は何ですか。
(a) Male (男性)
(b) Female (女性)

2. To which age group do you belong? どの年齢層に入りますか。
(a) $<17$
(d) 24-26
(b) $18-20$
(e) $27+$
(c) $21-23$

3. What is your native language? 母国語は何ですか。
(a) Japanese (日本語)
(b) Other (その他)

4. For how long have you been studying English? ごのくらいの期間英語を勉強 していますか。 
5. Which type of institution do you currently attend? 現在どのような大学で 英語を勉強していますか。
(a) Public university (公立大学)
(d) College (専門学校)
(b) Private university (私立大学)
(c) National university (国立大学)
(e) Other (その他)

6. What level of English classes do you currently take? 現在どのレベルの英語 の授業を受けていますか。
(a) Beginner (初級)
(b) Lower intermediate (準中級)
(c) Intermediate (中級)
(d) Upper intermediate (中級上)
(e) Advanced (上級)

7. What kind of English class(es) do you currently take? 現在どのような英語 の授業を受けていますか。
(a) General English (一般英語)
(b) Reading (読解)
(c) General writing (作文)
(d) English academic writing (アカデミック・ライテイング)
(e) English for academic purposes (EAP) (学術英語)
(f) English for specific purposes (ESP) (特定の目的のための英語)
(g) Conversation (会話)
(h) Listening (聴解)
(i) Grammar (文法)
(j) Other (その他)

8. Have you studied overseas before? 海外で英語を勉強したことがありますか。
(a) Yes (ある) (go to Question 9)
(b) No (ない) (go to Question 10)

9. Where, and for how long, did you study overseas? どこ・どのくらいの期間海 外で勉強しましたか。

\section{Section 2: Teacher Use of $L 1$}

10. What nationality is your English teacher? あなたの英語の先生は何人ですか。
(a) Japanese (日本人)
(b) Native English speaker (ネイティブ)
(c) I have both (どちらもいます)
(d) Other (その他) 
11. How often does your English teacher utilise your first language (L1) in the English classroom? あなたの先生は英語の授業でどれほど日本語を使用 していますか。
(a) Always (いつも) (80-100\%)
(d) Seldom (あまり) (20-40\%)
(b) Often (よく) (60-80\%)
(e) Rarely (めったに) (1-20\%)
(c) Sometimes (ときどき) (40-60\%)
(f) Never (ぜんぜん) (0\%)

12. For what reasons does your teacher use Japanese in your English classroom? あなたの先生は英語の授業でどのような場面で日本語を使用しますか。

Explaining English grammar (英語の文法を説明する時)

Explaining English vocabulary (英語の語彙を説明する時)

Explaining Western culture/ideologies (英語の文化などを説明する時)

Explaining English texts (英文を説明する時)

Explaining English listening passages (英語の聞き取りパッセージ

を説明する時)

Comparing English and Japanese structures (英語と日本語を比べる時)

Repeating something in Japanese after saying it first in English (最初に英語で言つてから日本語で繰り返す時)

Engaging in small-talk with your students (生徒と世間話をする時)

To save time (時間を節約する時)

To give instructions (指示を出す時)

To give feedback (フィードバックする時)

To give advice on study methods (勉強方法についてアドバイスをする時)

For classroom management (administration, discussing the course, etc.) (学級経営の為。例えば、コースについて話したりするなど)

For behavioural management (discipline, student organisation, etc.) (行動管理の為。例えば、規律や生徒の管理など)

$\square$ For task management (instructions, ensuring comprehension, maintaining task flow, etc.) (タスク管理の為。例えば、指示や理解の確認 など)

$\square \quad$ To ask students questions (生徒に質問をする時)

To answer students' questions (生徒の質問に答える時)

To summarise the lesson (授業を要約する時) 


\section{Section 3: Own Use of $L 1$}

13. Does your teacher allow you to use Japanese in your English classroom? 英語の授業で日本語を使っても、先生は構いませんか。
(a) Yes (はい,かまいません)
(b) No (いいえ、かまいます)

14. How often are you allowed to use Japanese in the English classroom? 英語の授業で、どのくらい日本語を使ってもいいですか。
(a) Always (いつも) (80-100\%)
(d) Seldom (あまり) (20-40\%)
(b) Often $(よ<)(60-80 \%)$
(e) Rarely (めったに) (1-20\%)
(c) Sometimes (ときどき) (40-60\%)
(f) Never (ぜんぜん) (0\%)

15. For what purpose(s) do you use Japanese when studying English? 授業以外で自分で英語を勉強している時に、何のために日本語を使用しますか。

To translate and better understand new vocabulary

(新しい語彙を訳してもつと深く理解するため)

To translate and better understand new grammar items

(新しい文法を訳してもつと深く理解するため)

To better understand difficult concepts

(難しい概念をもつと深く理解するため)

To better understand cultural items (文化をもつと深く理解するため)

To translate and better understand reading texts

(英文を訳してもつと深く理解するため)

$\square$ To translate and better understand listening passages

(英語のリスニングを訳してもつと深く理解するため)

To compare English and Japanese (英語と日本語を比べるため)

To plan my essays (英語のエッセイを計画するため)

To translate and better understand what I hear

(聞いたことを訳してもつと深く理解するため)

To save time (時間を節約するため)

To ask the teacher questions (先生に質問をするため)

To answer the teacher's questions (先生の質問に答えるため)

To discuss with friends about our English class

(友達と英語の授業について話すため)

To easily make study notes (簡単に勉強のノートを取るため)

To express my true identity (自分の本当にアイデンティティーを表すため)

Other (その他) 


\section{Section 4: Translanguaging}

16. To what extent do you agree with the idea that "foreign language education should be thought of as bilingual education"?「外国語教育とはバイリ ンガル教育である」という考えについて、どれほど賛成しますか。

Not at all (賛成しない)（1)（2）(3)(4) (5) Completely agree (賛成する)

17. If you were to place yourself somewhere along this scale from 1 to 10 , where would you place yourself?このスケールの 1 から 10 まで、どこに自分 を置きますか。

Not at all bilingual (1) (2) (3) (4) (5) (6) (7) (8) (9) (10) Completely bilingual (全然バイリンガルじゃない) (バイリンガル)

18. Why do you think this? なぜそう思いますか。

19. Would you like to try a translanguaging approach to studying English in Japan? 日本の英語教育でトランスランゲージングをやってみたいと思いますか。

(a) Yes, definitely (はい、ぜひやりたいと思います) (go to Question 20)

(b) Yes, I would at least try it (はい、少なくともやってみたいと思います) (go to Question 20)

(c) Maybe (多分) (go to Question 20)

(d) No, probably not (いいえ、あまりやってみたくないと思います) (go to Question 21)

(e) No, definitely not (いいえ、全然やりたくないと思います) (go to Question 21)

20. Why do you think a translanguaging approach to studying English in Japan would be beneficial? 日本の英語教育でトランスランゲージングを使用 することは良いことだと思いますか。それはなぜですか。

21. Why do you think a translanguaging approach to studying English in Japan would be bad? 日本の英語教育でトランスランゲージングを使用すること は良くないことだと思いますか。それはなぜですか。 